\title{
DIE VERBAND VAN LEERPROSESVERANDERLIKES MET LEERSUKSES
}

\author{
DF LOTRIET \\ WJ COETSEE \\ JM SCHEPERS \\ Departement Menslikehulpbronbestuur \\ Randse Afrikaanse Universiteit
}

\begin{abstract}
The relationship between learning process variables and study success. The main objective of this study was to determine the relationship between the constructs "meaning orientation" (in-depth approach to study) "transformational conception" and "self-regulation" in the distance education context (TV-learning). A random sample of 1951 participants taken from a large financial institution yielded 263 usable questionnaires. The responses obtained to the 167 items were subjected to factor analysis and item analysis. Thereafter the intercorrelations between the learning process variables "approach to learning", "conceptions of learning" and "regulation strategies" were computed. The results indicate that although low correlations exist among the constructs "meaning orientation", "transformational conception" and "self-regulation", a moderate correlation was found between "reproducing orientation", "accumulating conception" and "external regulation". The implications of these findings are further discussed.
\end{abstract}

\section{OPSOMMING}

Die hoofdoel van die onderhawige studie was om te bepaal of daar ' $\mathrm{n}$ verband tussen die konstrukte "betekenisoriëntasie" (dieptebenadering tot leer), "transformasionele begrip" en "selfregulering" in die afstandsonderrigkonteks (TV-leer) bestaan. 'n Ewekansige steekproef van 1951 deelnemers geneem uit ' $\mathrm{n}$ groot finansiële instelling het 263 bruikbare vraelyste opgelewer. Die response op 167 items is aan faktor- en itemontledings onderwerp. Daarna is die interverwantskappe tussen die leerprosesveranderlikes, naamlik "benadering tot leer", "begrip van leer" en "reguleringstrategieë" bepaal. Die resultate dui daarop dat alhoewel daar lae verbande tussen die konstrukte "betekenisoriëntasie", "transformasionele begrip" en "selfregulering" bestaan daar tog matig verbande tussen die konstrukte "reproduserende oriëntasie", "akkumuleringsbegrip" en "eksterne regulering" bevind is. Die implikasies van die bevindinge word verder bespreek.

\section{SYNOPSIS}

Accademic institutions and organisations are constantly searching for meaning in various learning contexts. This meaning enables them to obtain a better understanding of the factors that are more likely to enhance the chances of academic success in various learning contexts. Distance education is no exception. The meaning obtained from research empowers organisations and their students to build sound knowledge bases and deep understandings of the interrelationship between the various constructs.

The aim of the study was to determine the possible relationship between the constructs "meaning orientation" (in - depth approach to study), "transformational conception" and "self-regulation" in the distance education context (Tv-learning). The second objective was to define deep and surface approaches in the Tv-learning context.

"Meaning orientation" (in-depth approach to study) refers to the student's efforts to: understand the learning material properly; bring the learning context into relation with previous experiences; and build up a broad frame of reference where the relationships and inter dependencies of the underlying components are indicated. "Transformational conception" refers to the student's abillity to construct meaning, bring about transformation and go beyond the information given. "Self-regulation" refers to the student's ability to act independantly in the learning process and to take initiative in diagnosing their own learning needs. "Self-regulation" refers to the formulation of learning objectives, location of resources, the fulfillment of objectives, and the evaluation of the extent to which these objectives are met.

A correlation design was used to test both the research hypothesis and the postulates. The research group was composed of a random sample of 1951 participants taken from a large financial institution that yielded 263 usable questionnaires. Three questionnaires were

Versoeke vir afskrifte moet gerig aan: DF Lotriet, Departement Menslike

Hulpbronbestuur, RAU, Posbus 524, Auckland Park, 2006 completed. The Lancaster Approaches to Study and Course Perception Questionnaire (LASCPQ) was used to measure "orientation to learning" (approach to learning). The Reflections on Learning Inventory (ROLI) was used to measure "conceptions of learing". The Inventory of Learning Styles in Higher Education was used to measure "regulation strategies" as well as "motivation for studies".

Results inidcate that although a low correlation exists among the concstucts "meaning orientation", "transformational conception" and "self-regulation", a moderate to high correlation was found among "reproducing orientation", "accumulating conception" and "external regulation". Results also indicate that a "deep approach to study" in the Tv-learning context is associated with: "motivation for studies", "transformational conception", "accumulating conception of learning", "external regulation", "personal motivation for studies" and "self-regulation". The "surface approach to study" is associated with "reproducing orientation", "lack of regulation" and "meaning orientation".

The "deep approach to study", that is thus normally associated with study success in higher education, is defined differently in the Tvlearning context. This confirms the uniqueness of the Tv-learning, distance education learner as well as the unique demands that are made on the context. There is thus a need for a break away from the traditional definition of factors that are normally associated with study success in higher education. Provision should be made for a wider variety of strategies that learners can take up in certain learning contexts. This will enable students and learner assistants to obtain greater insight into the structuring and presentation of the learning as well as the creation of an environment conducive for learning.

Die toenemende belangrikheid van die benutting van alternatiewe onderrigmetodologieë in die Suid-Afrikaanse konteks is welbekend. Aspekte soos lae ekonomiese groeikoers; hoë bevolkingsgroei; lae geletterdheids- en vaardigheidsvlakke van die bevolking; beperkte finansiële hulpmiddele en infrastruktuur (Greyling, 1993; Slabbert \& De Villiers, 1998; Van Dyk, Nel, Loedloff \& Haasbroek, 1997) 
plaas opnuut die fokus op afstandsonderrig as 'n alternatief vir residensiële kontakonderrig. Die afstandsonderrigveld word egter deur 'n eiesoortige problematiek gekenmerk. Leerder-isolasie (Greyling, 1993), hoë uitvalsyfers (Phipps \& Merisotis, 1999) en gebrekkige navorsing (Holton, 1996; Phipps \& Merisotis, 1999) dien as voorbeelde in dié verband.

Verskeie navorsing kan uit die literatuur geidentifiseer word wat dui op aspekte wat 'n invloed op studiesukses uitoefen. Aspekte soos vermoë (Wexley \& Latham, 1981); houding van leerders (Ford \& Noe, 1987; Noe, 1986); motivering van die leerders (Mathieu, Tannenbaum \& Sallas, 1992); vertroue in eie vermoëns (Tannenbaum, Mathieu, Sallas \& Cannon-Bouwers, 1991); selfgerigtheid in die leerproses (Durr, Guglielmino \& Guglielmino, 1996); geslag (Tziner \& Falbe, 1993); leergereedheid (Van Zyl, 1991); leerstyl (Ramsden, 1985); vorige ervaring met leer (Biggs, 1989) en begrip van leer (Biggs, 1989; Entwistle \& Tait, 1990) kan in die verband onderskei word. Voorts kan aspekte soos die student se oriëntasie tot leer (Ramsden, 1985); benadering tot leer (Biggs, 1989; Entwistle \& Tait, 1990; Ramsden, 1985; Richardson \& Morgan, 1999) en die mate waarin leeruitkomste bereik is (Ramsden, 1985) as verdere faktore in leersukses beskou word.

Uit bostaande is dit duidelik dat ' $n$ komplekse aantal veranderlikes ' $n$ invloed op die leersukses van leerders, in ' $n$ verskeidenheid van onderrigkontekste, kan uitoefen. Die vraag kan egter gevra word of veranderlikes wat in die tradisionele onderrigkonteks ' $n$ invloed op leersukses uitoefen, ook na ander onderrigkontekste, byvoorbeeld die televisieleerkonteks, veralgemeenbaar is? Resente navorsing deur Phipps en Merisotis (1999), waar afstandsonderrignavorsingsresultate meta-analities ontleed is, het bepaalde leemtes in die verband uitgewys, naamlik:

- Belangrike veranderlikes wat 'n invloed op leersukses uitoefen, word nie in aanmerking geneem of voldoende beheer nie (vergelyk ook die sienswyses van Brinkerhoff, 1987; Holton, 1996 in die verband).

- Metodologiese leemtes, veral ten opsigte van die betroubaarheid en geldigheid van meetinstrumente, asook in die samestelling van steekproewe, is aangedui.

- Die invloed van afstandsonderrigtegnologieë (onderskeie kombinasies daarvan) op studentetevredenheid word ten koste van studente se leer-prosesse beklemtoon. Dit beteken dat verdere navorsing ten opsigte van "hoe studente in " $n$ verskeidenheid van kontekste leer", dringend noodsaaklik is. Nie alleen sal dit ' $n$ aanduiding gee van die wyse waarop daar in ' $\mathrm{n}$ verskeidenheid van kontekste gedoseer behoort te word nie, maar ook watter leerbenadering in ' $\mathrm{n}$ bepaalde konteks meer doeltreffend benut kan word (vergelyk ook die sienswyse van Dickinson, 1999 in dié verband).

Verskeie teoretiese raamwerke, waarin studenteleerprosesse geoperasionaliseer word, kan in dié verband onderskei word. Wanneer die benaderinge van Biggs (1985); Entwistle (1992); Entwistle en Tait (1990); en Ramsden (1985) ontleed word, blyk dit dat leerprosesveranderlikes soos die benadering tot die leerproses, die konteks waarbinne leer plaasvind en die begrip van die leerproses ' $\mathrm{n}$ beduidende invloed op leersukses kan uitoefen. Ten spyte daarvan dat dié veranderlikes in die literatuur deeglik ondersoek is (vergelyk byvoorbeeld studies gedoen deur Biggs, 1995; Marshall \& Summers, 1999; Mji, 1998; Mji \& Glencross, 1999; Zhang, 2000), is die studies hoofsaaklik in residensiële omgewings, op voltydse voorgraadse studente uitgevoer. Slegs enkele kontemporêre, relevante studies, soos van toepassing in die Suid-Afrikaanse konteks (byvoorbeeld 'n studie gedoen deur Akande, 1998 met 750 voorgraadse studente) kon in die literatuur opgespoor word. Waar die genoemde veranderlikes as vertrekpunt in die onderhawige studie dien, is dit gepas om dié veranderlikes kortliks toe te lig.

\section{Leerprosesveranderlikes}

Benadering tot die leerproses

Skrywers soos Biggs (1993); Morgan (1993); Ramsden (1985); en Roussouw en Parsons (1994) is dit eens dat die benadering wat deur leerders in die leerproses gevolg word as ' $n$ belangrike bepaler van studiesukses beskou kan word. Twee komponente kan in dié verband onderskei word, naamlik die leerder se oogmerk met die studie en die leermetodologie wat deur die leerder gevolg word (Ramsden, 1985). Betreffende die leermetodologie stel Entwistle en Tait (1990); Lotriet (1990); en Ramsden (1985) dit dat leerders enersyds kan poog om die leermateriaal deeglik te begryp, die leerinhoud met vorige ervaringe in verband te bring en ' $n$ breë verwysingsraamwerk te vorm, waar die verwantskappe en interafhanklikhede tussen die onderskeie komponente aangedui word. Die voorafgaande is ook aanduidend van ' $n$ dieptebenadering tot leer wat deur die leerder gevolg word. Hierteenoor kan leerders poog om bloot die leerinhoud te memoriseer, die sillabus slaafs na te volg, te reproduseer en om aan die minimum taakvereistes te voldoen. Laasgenoemde verwys na "n oppervlakbenadering tot leer waar die leerder poog om slegs aan die minimum evalueringsvereistes te voldoen (Morgan, 1993). Indien beskouinge van Entwistle en Tait (1990); en Ramsden (1985) onder die loep geneem word, blyk dit dat suksesvolle studente, in die residensiële onderrigkonteks, eerder ' $\mathrm{n}$ dieptebenadering as oppervlakbenadering in die leerproses benut.

Indien die oppervlakbenadering tot leer benut word, word daar ook in die literatuur daarna verwys as die reproduserende oriëntasie tot leer (Schmeck, 1988). Net so word daar na die dieptebenadering as 'n betekenisoriëntasie verwys (Schmeck, 1988). Die benutting van dié terminologie in die literatuur as wisselterme met die gepaardgaande tiperende eienskappe wat met die term verband hou, skep semantiese verwarring en 'n eiesoortige problematiek. Dit blyk dat die onderskeie definisies van "n "dieptebenadering tot leer" met die "betekenisoriëntasie" wat "n leerder aan 'n leersituasie heg, ooreenstem; terwyl die onderskeie definisies van die "oppervlakbenadering" met die "reproduserende oriëntasie" ooreenstem (Ramsden, 1985) en derhalwe word die onderskeie terme as wisselterme benut.

Aansluitend hierby stel Biggs (1993) dit dat 'n verdere leermetodologie, naamlik ' $\mathrm{n}$ strategiese benadering tot leer, onderskei kan word. Leerders wat so ' $\mathrm{n}$ tipe benadering in die leerproses volg, sal geneig wees om die maksimum uitset (dit wil sê hoë punte) met die minimum inset te verkry. Taktiese insette, soos die bestudering van vorige vraestelle en optimale tydsbestuur kan as tiperend van die tipe benadering beskou word (Biggs, 1993; Entwistle \& Tait, 1990).

Verbandhoudend met die voorafgaande meen Pintrich (1995); Schunk (1986); en Vermunt (1992) dat leerders oor doeltreffende strategieë moet beskik om die leerproses doeltreffend te bestuur. Vermunt (1992) verklaar in dié verband dat drie tiperende strategieë onderskei kan word, naamlik 'n eksterne reguleringstrategie, 'n selfregulerende strategie en 'n gebrek aan 'n reguleringstrategie. Leerders wat oor selfregulerende strategieë beskik, sal geneig wees om meer outonoom in die leerproses op te tree. Knowles $(1984, p$. 37) noem in die verband “... they take the initiative in diagnosing their own learning needs, in formulating learning objectives, in locating resources to fulfill objectives, and in evaluating the extent to which they meet objectives". Dit beteken dat die leerder verantwoordelikheid vir leersukses neem en waarskynlik oor hoë vlakke van selfprobaatheid beskik (Gallagher, 1994; Warr \& Bunce, 1995) wat aanduidend van die leerder se vertroue in sy/haar eie vermoëns is. Hierteenoor sal 'n leerder wat ' $n$ eksterne reguleringstrategie benut, geneig wees om mislukking aan eksterne faktore toe te skryf en hulpeloosheid in die leerproses te ervaar (Vermunt, 1992). Daar kan gespekuleer word dat die voorafgaande na psigologiese onvolwassenheid verwys (Knowles, 1984) en dat die leerder 'n oormatige afhanklikheid ten opsigte van die leerbegeleier, medeleerders en leerinhoud mag openbaar. Verbandhoudend met die voorafgaande sal leerders wat geen reguleringstrategie volg nie waarskynlik beskou kan word as individue wat nie oor die vermoë beskik om beheer oor die inhoud, verloop en resultaat van die leerproses te 
neem nie (Vermunt, 1992). Die afleiding kan gemaak word dat daar ' $\mathrm{n}$ sterk ooreenstemming bestaan tussen leerders wat ' $\mathrm{n}$ eksterne reguleringstrategie in die leerproses volg en leerders wat geen reguleringstrategie benut nie.

Twee faktore, naamlik leerervaring (Marton \& Saljo, 1984; Ramsden, 1985) en leermotivering (Tannenbaum \& Yukl, 1992; Wlodkowski, 1985) kan ' $n$ invloed op die keuse van ' $n$ leermetodologie en die wyse waarop die leerproses bestuur word, uitoefen. Dit beteken dat vorige opvoedkundige ervarings (byvoorbeeld die skoolsisteem), vaardighede van leerders vereis wat ' $\mathrm{n}$ oppervlakbenadering tot leer by leerders stimuleer en aanmoedig. Aspekte soos memorisering en die reprodusering van kennis word as die vernaamste kriteria benut om studiesukses te bepaal. Voorts kan die motiveringsvlak van die leerder ' $n$ bepaalde invloed op die wyse waarop leerinhoud benader en bestuur word, uitoefen. Die voorafgaande is veral van toepassing op die volwasseneleerder en Knowles, Holton en Swanson (1998) noem in die verband dat volwasseneleerders 'n lewens-, taak- of probleemgesentreerde benadering tot leer volg en oor ' $n$ dringende tydsperspektief betreffende die aanwending of die gebruik van nuut aangeleerde kennis beskik. Daar kan gespekuleer word dat indien die leerinhoud toepaslik en aanwendbaar is (Knowles et al., 1998) volwasseneleerders selfregulerend sal optree en sal poog om die leermateriaal met vorige ervaringe in verband te bring. Dit beteken dat die volwasseneleerder 'n breë verwysingsraamwerk, waar die verwantskappe tussen die onderskeie konsepte aangedui word, in die leerproses sal benut en derhalwe ' $\mathrm{n}$ dieptebenadering in die leerproses sal volg.

\section{Die leerkonteks waarbinne die leerproses plaasvind}

Die rol van die leerkonteks en die invloed daarvan op studiesukses is welbekend (vergelyk ook die sienswyses van Broad \& Newstrom, 1992; Burke, 1997; Ford \& Weissbein, 1997 in dié verband). Wanneer die beskouinge van skrywers soos Biggs (1993); Entwistle en Ramsden (1983); Greyling (1993); en Lotriet (1990) betreffende die invloed van die leerkonteks op leersukses, in oënskou geneem word, blyk dit dat die volgende komponente studiesukses kan beïnvloed:

- Die wyse waarop die leerbegeleier aan sy/haar toegewysde rol en funksie uitvoering gee. Smit (soos aangehaal deur Greyling, 1993, p. 40) stel in die verband dat "genuine (andragogic) support depends to a great extent on the tutor's ability to perform the tasks of negotiating, contracting, liaising, advising, monitoring, counselling, referring, teaching, assessing, coaching, disciplining, representing, giving of feedback, evaluating, refereeing, coping with emotional attachment, identifying themes, target setting". Die voorafgaande is aanduidend van die belangrike rol wat die leerbegeleier in die leerproses speel.

- Die leertaak soos dit gestalte vind in die kurrikulumontwerp, kompleksiteit, relevansie van die leerinhoud, die wyse waarop formatiewe en summatiewe evaluering plaasvind, terugvoer deur die leerbegeleier aan die leerder gegee word, dien as voorbeelde van enkele faktore wat die leertaak positief kan beïnvloed.

- Kontekstuele faktore, wat ' $\mathrm{n}$ invloed op studiesukses kan uitoefen, soos die akademiese instelling se verbintenis tot kwaliteitonderrig en die handhawing van akademiese standaarde, leerbegeleier-student-verhouding sowel as die beskikbaarstelling van hulpbronne kan as verdere faktore in die verband onderskei word.

Bostaande uiteensetting is aanduidend van die veelheid leerkonteksveranderlikes wat ' $n$ invloed op studiesukses kan uitoefen. Die belangrikheid van die veranderlikes is egter in die persepsie van die leerder geleë ten opsigte van die invloed wat die veranderlikes op sy/ haar studiesukses uitoefen (Biggs, 1993; Hackman \& Walker, 1990; Howard \& Ault, 1992; Ramsden \& Entwistle, 1981; Rossouw \& Parsons, 1994). Daar kan geredeneer word dat indien leerders die leertaak as oormatig kompleks beskou, die relevansie van die inhoudelike bevraagteken word en die formatiewe sowel as summatiewe evaluering as onbillik beleef word, die leerders meer geneig sal wees om 'n oppervlakbenadering (teenoor ' $\mathrm{n}$ diepte-benadering) in die leerproses te volg. Die voorafgaande is ook aanduidend van die belangrike rol wat leerderpersepsies in die onderriggebeure speel. $\mathrm{Na}$ verwagting kan die akademiese instelling ' $\mathrm{n}$ belangrike rol in die beinvloeding van leerderpersepsies speel deur te verseker dat aspekte soos doeltreffende onderrigmedia, kurrikulumontwerp, leerder-begeleiding en ondersteuning in die leerproses gestalte vind. Voorts moet die onderrigontwerp, selfregulerende gedrag en die benutting van diepteleerbenaderings fasiliteer. 'n Belangrike implikasie wat uit die voorafgaande voortspruit, is die doelbewuste en georganiseerde bestuurspoging wat deur ' $n$ akademiese instelling geïnisieer behoort te word om leerderpersepsies positief te beinvloed.

Begrip van die leerproses

In die voorafgaande besprekings is aangedui dat leerders leerinhoud op verskillende wyses benader sowel as verskillende bestuursmeganismes in die leerproses benut. Voorts is aangedui dat die wyse waarop leerders die leertaak benader en bestuur, 'n bepaalde invloed op leersukses kan uitoefen. Aansluitend by die voorafgaande sal die betekenis wat deur 'n leerder aan die leerproses geheg word, 'n verdere invloed op leersukses uitoefen. Wanneer die beskouinge van Meyer en Boulton-Lewis (1999); Morgan (1993); en Saljo (1982) in dié verband onder die loep geneem word, blyk dit dat die begrip oftewel die betekenis wat leerders aan die leerproses heg in twee breë kategorieë verdeel kan word. Aan die een kant van die spektrum is daar leerders wat die leerproses as die akkumulering van feite, prosedures en die memorisering daarvan beskou. Aan die ander kant kan leer deur leerders beskou word as "... constructing meaning and transformation and going beyond the information given" (Morgan, 1993). 'n Moontlike afleiding wat in dié verband gemaak kan word, is dat leerders wat leer bloot as die akkumulering van feite en die memorisering daarvan beskou, geneig sal wees om ' $n$ oppervlakbenadering tot die leerproses voor te staan. Na verwagting sal so 'n tipe leerder ook geneig wees om 'n eksterne reguleringstrategie in die leerproses te benut (Vermunt,1992). Daarteenoor kan leerders wat oor 'n transformasionele begrip betreffende die leerproses beskik, eerder daarop ingestel wees om 'n dieptebenadering tot die leerproses te volg en volgens ' $n$ selfreguleringstrategie te handel (vergelyk ook die beskouinge van Entwistle \& Tait, 1990; Morgan, 1993; en Vermunt, 1992 in die verband).

Die manifestasie van leerbegrip (hetsy reproduserend of transformasioneel) kan egter as die wisselwerking tussen ' $n$ komplekse aantal veranderlikes beskou word. In die verband verklaar skrywers, soos byvoorbeeld Meyer en Boulton-Lewis (1999) en Van Wyk (1990), dat faktore soos kognitiewe strategieë, die aard van die leertaak, leerverwagtinge, die persepsies wat die leerder betreffende die leerkonteks huldig, vorige ervaring met leer, asook kulturele invloede die vorming van leerbegrip beïnvloed. In ooreenstemming met die beskouinge van Knowles (1984; 1989) en Knowles et al. (1998) betreffende die volwasseneleerder, kan leerbegripvorming as ' $n$ dinamiese eerder as ' $n$ statiese proses beskou word. Soos die leerder groei en ontwikkel, met ander woorde " ... has arrived at a self-concept of being responsible for one's own life, of being selfdirected" (Knowles, 1984, p. 9), sal die leerbegripparadigma verder uitgebou word. Dit beteken dat waar die leerder aanvanklik oor ' $\mathrm{n}$ beperkende leerbeskouing beskik het, dit oor ' $\mathrm{n}$ tydperk tot ' $\mathrm{n}$ transformasionele leerbelewenis uitgebou kan word. Aansluitend hierby verklaar Perry (soos aangehaal deur Morgan, 1993) dat regressering, na ' $n$ vorige ontwikkelingsfase kan plaasvind "... where the learner failed to progress and moved back to earlier stages in his or her development" (p. 64).

Die belangrikheid van leerbegrip, as ' $n$ veranderlike in leersukses, word in bogenoemde uiteensetting beklemtoon. In aansluiting hierby sou daar gespekuleer kon word dat leerders 
wat oor hoë vlakke van leerbewustheid beskik (met ander woorde begrip van wat leer werklik behels) in ' $n$ verskeidenheid van kontekste, hetsy residensiële of die televisieleerkonteks, groter leersukses kan behaal as leerders wat oor lae vlakke van leerbewustheid beskik.

\section{Probleemstelling}

In aansluiting by die voorafgaande teoretiese ontleding en met inagneming van die motivering vir die studie, kan die probleemstelling soos volg gestel word: Tradisioneel word suksesvolle leerders aan residensiële instellings getipeer as individue wat ' $n$ "dieptebenadering tot leer" benut; geneig is om "selfregulerend in die leerproses" op te tree; "intrinsiek gemotiveerd" is en " $n$ "transformasionele begrip" betreffende die leerproses huldig (vergelyk die sienswyses van Entwistle \& Tait, 1990; Lotriet, 1990 en Ramsden, 1985 in dié verband). Die vraag is egter of die voorafgaande tipering ook van toepassing op die televisieleerstudent gemaak kan word; of die geïdentifiseerde betekenisoriëntasie, tipe reguleringstrategieë en begrip van die leerproses tot die televisieleerkonteks veralgemeen kan word en of daar onderlinge verwantskappe tussen die konstrukte is.

\section{Doelstelling:}

Die hoofdoelstellings van die studie is die volgende:

- Die bepaling van die interverwantskappe tussen die konstrukte "betekenisoriëntasie"; "transformasionele begrip" en "selfregulering".

- Die definiëring van die diepte- en oppervlakbenaderings tot leer soos van toepassing in die televisieleerkonteks.

- Bestaande meetinstrumente aan faktor-en itemontledings te onderwerp om sodoende betroubare en geldige skale daar te stel.

$\mathrm{Na}$ aanleiding van die literatuurstudie, die probleemstelling en die doelstellings van die studie, word die volgende drie hipoteses (om die eerste gestelde doelwit te bereik) gestel:

Hipotese 1: Daar bestaan ' $\mathrm{n}$ statisties beduidende verband tussen betekenisoriëntasie en transformasionele begrip van leer.

Hipotese 2: Daar bestaan ' $\mathrm{n}$ statisties beduidende verband tussen betekenisoriëntasie en selfreguleringstrategieë.

Hipotese 3: Daar bestaan ' $\mathrm{n}$ statisties beduidende verband tussen transformasionele begrip van leer en selfregulering-strategieë.

Ten einde die tweede doelwit van die studie te bereik, word die volgende twee postulate geformuleer:

Potulaat 1: Na verwagting sal persone wat 'n dieptebenadering in die televisieleerkonteks benut intrinsiek gemotiveerd wees, oor ' $n$ transformasionele begrip van die leerproses beskik en ' $n$ selfgereguleerde strategie benut. Hierdie persone sal dan nie ekstern gereguleerd wees, ' $\mathrm{n}$ akkumuleringsbegrip opneem of ' $\mathrm{n}$ reproduserende oriëntasie in die leerproses benut nie.

Postulaat 2: Na verwagting sal persone wat 'n oppervlakbenadering in die televisieleerkonteks benut ekstrinsiek gemotiveerd wees, oor 'n akkumuleringsbegrip van die leerproses beskik en ' $n$ eksterne reguleringstrategie benut. Hierdie persone sal dan nie ' $n$ betekenisoriëntasie in die leerproses benut, selfgereguleerd optree of oor ' $n$ transformasionele begrip beskik nie.

\section{METODE}

\section{Die Steekproef}

Die navorsing is uitgevoer by ' $n$ Suid-Afrikaanse finansiële instelling. Vraelyste is aan al die werknemers gestuur wat as studente vir die 1997/1998 akademiese jaar ingeskryf was. Die totale populasie aan wie vraelyste gestuur is beloop 1951 waarvan 263 gerespondeer het. Die betrokke studente kom uit verskillende divisies, takke en streke en verteenwoordig die verskillende kultuurgroepe, geslagte en geografiese gebiede. Tweehonderd drie en sestig vraelyste is terugontvang. As rede vir die swak respons $(13,7 \%)$ en die talle studente wat verkies het om anoniem te bly, kan die volgende rede aangevoer word: Die betrokke organisasie het tydens die insameling van die gegewens groot veranderinge ondergaan wat sekere rasionaliseringsimplikasies tot gevolg gehad het. Om hierdie rede het baie van die studente verkies om anoniem te bly of glad nie die vraelyste in te vul nie, ondanks die feit dat die oogmerk van die beoogde studie duidelik aan die studente bekend gemaak is. Gevolglik kon die biografiese inligting van slegs 163 studente verkry word. Die biografiese gegewens verskyn in Tabel 1 .

\section{TABEL 1}

BIOGRAFIESE BESONDERHEDE VAN DIE RESPONDENTE

\begin{tabular}{|c|c|c|}
\hline Fre & kwensie (f) & Persentasie (\%) \\
\hline \multicolumn{3}{|l|}{ 1. GESLAG } \\
\hline Aantal mans & 101 & 38,4 \\
\hline Aantal vroue & 159 & 60,4 \\
\hline Onbekend & 3 & 1,1 \\
\hline Totaal $(\mathrm{N})$ & 263 & 100 \\
\hline \multicolumn{3}{|l|}{ 2. HUWELIKSTATUS } \\
\hline Getroud & 99 & 37,6 \\
\hline Ongetroud & 50 & 19,0 \\
\hline Geskei & 14 & 5,3 \\
\hline Onbekend & 100 & 38,0 \\
\hline Totaal $(\mathrm{N})$ & 263 & 100 \\
\hline \multicolumn{3}{|l|}{ 4. AANTAL JARE DIENS } \\
\hline 0 tot 5 jaar & 75 & 28,5 \\
\hline 6 tot 10 jaar & 50 & 19,0 \\
\hline $11->$ & 37 & 14,0 \\
\hline Onbekend & 101 & 38,4 \\
\hline Totaal $(\mathrm{N})$ & 263 & 100 \\
\hline \multicolumn{3}{|l|}{ 5. OUDERDOM } \\
\hline $20-29$ & 63 & 23,9 \\
\hline $30-39$ & 70 & 26,6 \\
\hline $40->$ & 30 & 11,4 \\
\hline Onbekend & 100 & 38,0 \\
\hline Totaal $(\mathrm{N})$ & 263 & 100 \\
\hline \multicolumn{3}{|l|}{ 7. POSISIE IN ORGANISASIE } \\
\hline Klerklike Pos & 62 & 23,5 \\
\hline Bestuursposisie & 15 & 5,7 \\
\hline Toesighoudende hoedanigheid & 28 & 10,6 \\
\hline Bemarking & 9 & 3,4 \\
\hline Spesialis & 47 & 17,8 \\
\hline Semi-/ongeskoolde arbeid & 2 & 0,8 \\
\hline Onbekend & 100 & 38,0 \\
\hline Totaal $(\mathrm{N})$ & 263 & 100 \\
\hline
\end{tabular}

Uit ' $\mathrm{n}$ nadere beskouing van Tabel 1 blyk dit dat van die 163 respondente $60,4 \%$ dames is. Die oorgrote meerderheid van die respondente is getroud, en slegs $5,3 \%$ is geskei. Die meeste van die respondente $(28,5 \%)$ het vyf jaar of minder diens. Wat die respondente se ouderdom betref, is $23,9 \%$ jonger as 29 jaar, $26,6 \%$ is tussen 30 en 40 jaar en $11,4 \%$ is 40 jaar en ouer. Die meeste van die respondente is op klerklike vlak aangestel $(23,5 \%)$, gevolg deur die wat as spesialiste aangestel is $(17,8 \%)$.

\section{Meetinstrumente}

Drie geskikte meetinstrumente is vir die doeleindes van hierdie studie benut. Die drie instrumente, naamlik die Lancaster Approaches to Study and Course Perceptions Questionnaire (LASCPQ); die Reflections on Learning Inventory (ROLI) en die Inventory of Learning Styles in Higher Education sal vervolgens in meer besonderhede bespreek word.

Lancaster Approaches to Study and Course Perceptions Questionnaire (LASCPQ) 
Die LASCPQ is deur Ramsden (1983) ontwerp en meet 'n student se "benadering tot leer". Dit verskaf 'n meting van drie interaktiewe benaderings, asook "n "styl-en afwykingskaal" wat verband hou met die student se benadering tot leer. Die instrument verteenwoordig sestien faktore. Die faktore sluit vier oorhoofse oriëntasies tot leer in. Onder elkeen van die vier oriëntasies tot leer ressorteer vier benaderings tot leerveranderlikes (kyk Tabel 2).

'n Itemontleding is deur Ramsden (1983) op hierdie meetinstrument uitgevoer. Ofskoon die Cronbach Alfa koëffisiënte wat gelewer is as redelik laag beskou kan word, is die vraelys nogtans as aanneemlik vir navorsingsdoeleindes beskou. Op grond van die feit dat die instrument deur Lotriet (1990); Morgan (1993); en Ramsden (1985) in verskillende leerkontekste gebruik is en beduidende resultate tot gevolg gehad het, is dit as aanneemlik vir die beoogde studie beskou.

TABel 2

MEeTinstrumenTE

Cronbach alfa Aantal Items (N)

A LANCASTER APPROACHES TO STUDY AND COURSE PERCEPTIONS QUESTIONNAIRE (LASCPQ)

1. Betekenisoriëntasie tot leer

Dieptebenadering

Verbandhoudende idees

Gebruik van bewyse

Intrinsieke motivering

0,56

0,47

0,38

0,72

4

\section{0,49}

0,51

0,45

0,78

Sillabusgebondenheid

Vrees vir mislukking

Ekstrinsieke motivering

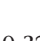

0,32

0,71

0,60

0,58

Negatganiseerde studiemetodes

Prestasiemotivering

4. Styl en afwykings-van-leer-oriëntasie Begripsleer

Globetrotting-holis

Operasionele leer

Sorgloosheid

Totaal

0,36

0,49

0,42

B REFLECTIONS ON LEARNING INVENTORY (ROLI)

Akkumulering

Herroeping

Begrip voor memorisering

Plig

Versameling van feite

Kennistoename

Memorisering voor begrip

Onafhanklike denke

' $n$ Anderse beskouing van goed

Kennis is diskreet en feitlik

Totaal

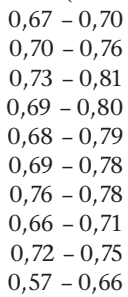

5

C INVENTORY OF LEARNING STYLES IN HIGHER EDUCATION

1. Reguleringstrategieë

Selfregulering Leerproses en leerresultaat Leerinhoud

Eksterne regulering Leerproses Leerresultaat

Gebrek aan regulering

Totaal

$$
0,81
$$

$$
0,75
$$$$
0,78
$$

0,78
0,78

0,78
0,67

0,71

0,68

2. Motivering vir studie

Persoonlike belangstellings

Sertifikaatgerigtheid

Toetsgerigtheid

Beroepsgerigtheid

Ambivalensie

Totaal
Reflections on Learning Inventory (ROLI)

Die instrument is deur Meyer en Boulton-Lewis (1999) ontwerp en meet ' $n$ student se begrip van leer deur middel van 10 interaktiewe leerveranderlikes, soos aangedui in Tabel 2. 'n Beskouing van Tabel 2 toon dat die meetinstrument matig tot hoë Cronbach Alfa koëffisiënte gelewer het en dus oor aanneemlike metriese eienskappe beskik.

\section{Inventory of Learning Styles in Higher Education}

Dié instrument is deur Vermunt (1994) ontwerp en meet twee leerstylveranderlikes, naamlik "reguleringstrategieë" en "motivering vir studie".

Die veranderlikes wat betrekking het op "reguleringstrategieë" verskaf metings van sewe interaktiewe strategieë terwyl die "motivering vir studie"-veranderlike metings van vyf interaktiewe oriëntasies verskaf. Sowel die "reguleringstrategieë" as die "motivering vir studie"-veranderlikes hou verband met die student se "leerstyl". Die faktore onderliggend aan bogenoemde vraelyste sal opnuut vir die huidige studie bepaal word, en slegs die skale met aanneemlike betroubaarhede sal behou word.

\section{PROSEDURE}

Die respondente is via die televisie-netwerk in kennis gestel van die beoogde studie. ' $n$ Dokument wat die prosedure vir die beantwoording van die drie vraelyste uiteensit, is aan die studente deur die organisasie se interne pos gestuur, vergesel van 'n geadresseerde koevert. Die respondente het deur die vrae gewerk, en enige onduidelikhede is deur die navorser opgeklaar. Die respondente is versoek om die vraelyste binne drie weke, in die koeverte wat voorsien is, aan die organisasie se skakelpersoon terug te stuur. Die respondente het die keuse gehad om anoniem te bly, of hul name op die vraelyste in te vul.

\section{Statistiese ontleding}

Nadat die data terugontvang is, is dit deur die Statistiese Konsultasiediens van die Randse Afrikaanse Universiteit ontleed.

\section{RESULTATE}

Ten einde die faktorstruktuur van die Lancaster Approaches to Study and Course Perceptions Questionnaire, die Relflections on Learning Inventory en die Inventory of Learning Styles in Higher Education vir Suid-Afrikaanse omstandighede te bepaal, is elkeen van die vraelyste aan ' $n$ hooffaktorontleding onderwerp.

Om die effek van differensiële skeefheid van die items van die onderskeie vraelyste teen te werk, en die ware struktuur van elkeen van die vraelyste te bepaal, is die volgende prosedure gevolg:

Die items van elke vraelys is geinterkorreleer en die eigenwaardes van die ongereduseerde interkorrelasiematrikse is bereken. Ooreenkomstig Kaiser (1961) se kriterium is die getal faktore vir elkeen van die vraelyste bepaal volgens die getal eigenwaardes groter as een.

Vervolgens is die gespesifiseerde getal faktore vir elke vraelys onttrek en die verkreë faktore na eenvoudige struktuur geroteer met behulp van die Varimaksrotasie.

Voorts is subtellings vir elke faktor gevorm deur die items met hoë ladings op elke faktor saam te voeg. Die subtellings is vervolgens geinterkorreleer (vir elke vraelys afsonderlik) en die matrikse van interkorrelasies aan faktorontleding onderwerp. Die verkreë faktormatrikse is na eenvoudige struktuur geroteer met behulp van die Direct Oblimin-prosedure.

Die Lancaster Approaches to Study and Course Perceptions Questionnaire het ses faktore opgelewer waarvan drie swak bepaal was, gevolglik is slegs drie faktore behou. Die Reflections on 
Learning Inventory het twee faktore opgelewer en albei is behou. Die Inventory of Learing Styles in Higher Education het vier faktore opgelewer en al vier is behou.

Vervolgens is nege verskillende skale gevorm deur die items met hoë ladings vir elke faktor saam te voeg. Hierdie skale is voorts aan itemontleding onderwerp en die betroubaarhede van die skale is met behulp van Cronbach se koëffisiënt alfa bepaal. Die verkreë betroubaarhede verskyn in Tabel 3.

TABel 3

BETROUBAARHEIDSKOËFFISIËNTE VAN DIE ONDERSKEIE SKALE

\begin{tabular}{lc}
\hline Skale & $\begin{array}{c}\text { Betroubaarheidskoëffisiënte } \\
\text { (Cronbach alfa) }\end{array}$ \\
\hline $\begin{array}{l}\text { Skaal 1: } \\
\text { Motivering vir studie (intrinsiek/ekstrinsiek) }\end{array}$ & 0,730 \\
Skaal 2: & 0,835 \\
Reproduserende oriëntasie & \\
Skaal 3: & 0,650 \\
Betekenisoriëntasie & \\
Skaal 4: & 0,934 \\
Akkumuleringsbegrip van leer & \\
Skaal 5: & 0,821 \\
Transformasionele begrip van leer & \\
Skaal 6: & 0,841 \\
Selfregulering & \\
Skaal 7: & 0,794 \\
Gebrek aan regulering & \\
Skaal 8: & 0,707 \\
Eksterne regulering & \\
Skaal 9: & \\
Persoonlike motivering vir studie & 0,802 \\
\hline
\end{tabular}

'n Inspeksie van Tabel 3 toon dat die betroubaarheidskoëffisiënte wissel van 0,650 tot 0,934 . Slegs een koëffisiënt is laer as 0,700 . Die skale kan gevolglik met vrug in navorsing gebruik word.

Ten einde die gestelde hipoteses te toets, is die nege skale geinterkorreleer. Die matriks van interkorrelasies verskyn in Tabel 4.

Tabel 4 toon die volgende verbande tussen "benadering tot leer", "begrip van leer" en "reguleringstrategieë". Die "intrinsieke/ekstrinsieke motivering vir studie" (benadering tot leer) hou matig verband met "transformasionele begrip" $(0,566)$, "selfregulering" $(0,433)$ en "eksterne regulering" $(0,480)$. Die "reproduserende oriëntasie" (benadering tot leer) hou matig verband met "akkumuleringsbegrip" $(0,445)$ en matig tot hoog met "gebrek aan regulering" $(0,626)$. Sowel "transformasionele" $(0,462)$ as "akkumuleringsbegrip" $(0,406)$ hou matig verband met "eksterne regulering". "Akkumuleringsbegrip" het "n matig tot hoë verband met "transformasionele begrip" $(0,634)$ getoon.

Hieruit kan afgelei word dat 'n matig tot hoë verband tussen "benadering tot leer", "begrip van leer" en "reguleringstrategieë" bestaan. ' $n$ Matige verband kom voor tussen "transformasionele begrip" en "eksterne regulering" $(0,462)$. Lae verbande kom voor tussen "betekenisoriëntasie" en "selfregulering" (0,028); "betekenisoriëntasie" en "eksterne regulering" $(0,047)$ en "betekenisoriëntasie" en "gebrek aan regulering" $(0,324)$.

Teenstrydig met wat verwag is, is daar ' $\mathrm{n}$ lae verband tussen "selfregulering" en "betekenisoriëntasie" $(0,028)$ en tussen "eksterne regulering" en "gebrek aan regulering" $(-0,009)$. "Betekenisoriëntasie" het ook "n lae verband met "transformasionele begrip" $(0,190)$ en "selfregulering" $(0,028)$ getoon. Wat wel na verwagting bevind is, is die volgende: "reproduserende oriëntasie" hou matig verband met "akkumuleringsbegrip" $(0,445)$ en matig tot hoog met "gebrek aan regulering" $(0,626)$. "Akkumuleringsbegrip" hou matig verband met "eksterne regulering" $(0,406)$. Die hoogste negatiewe korrelasie is gevind tussen "gebrek aan regulering" en "intrinsieke/ekstrinsieke motivering" $(-0,153)$. Hieruit kan afgelei word dat alhoewel daar nie tussen die drie ter sake leerprosesveranderlikes (begrip van leer, benadering tot leer en reguleringstrategieë) oral hoë verbande bestaan nie, is beduidende verbande tussen al drie skale gevind.

Ten einde die faktore (dimensies) onderliggend aan die interkorrelasies van die verskillende skale te bepaal, is die matriks van interkorrelasies aan faktorontleding onderwerp. Die eigenwaardes van die ongereduseerde interkorrelasiematriks verskyn in Tabel 5 .

TABel 5

EIGENWAARDES VAN ONGEREDUSEERDE INTERKORRELASIEMATRIKS

\begin{tabular}{cc}
\hline Wortel & Eigenwaarde \\
\hline 1 & 3,179 \\
2 & 1,934 \\
3 & 0,875 \\
4 & 0,738 \\
5 & 0,682 \\
6 & 0,632 \\
7 & 0,466 \\
8 & 0,295 \\
9 & 0,198 \\
Spoor & 9,000 \\
\hline
\end{tabular}

TABeL 4

MATRIKS VAN INTERKORRELASIES VAN DIE ONDERSKEIE SKALE

\begin{tabular}{|c|c|c|c|c|c|c|c|c|c|}
\hline & 1 & 2 & 3 & 4 & 5 & 6 & 7 & 8 & 9 \\
\hline 1. Motivering vir studie (intrinsiek/ekstrinsiek) & 1,000 & 0,061 & 0,000 & 0,348 & 0,566 & 0,433 & $-0,153$ & 0,480 & 0,406 \\
\hline 2. Reproduserende oriëntasie & 0,061 & 1,000 & 0,381 & 0,445 & 0,245 & $-0,125$ & 0,626 & 0,309 & 0,185 \\
\hline 3. Betekenisoriëntasie & 0,000 & 0,381 & 1,000 & 0,134 & 0,190 & 0,028 & 0,324 & 0,047 & 0,140 \\
\hline 4. Akkumuleringsbegrip van leer & 0,348 & 0,445 & 0,134 & 1,000 & 0,634 & 0,288 & 0,173 & 0,406 & 0,368 \\
\hline 5. Transformasionele begrip van leer & 0,566 & 0,245 & 0,190 & 0,634 & 1,000 & 0,226 & $-0,021$ & 0,462 & 0,420 \\
\hline 6. Selfregulering & 0,433 & $-0,125$ & 0,028 & 0,288 & 0,226 & 1,000 & $-0,093$ & 0,263 & 0,270 \\
\hline 7. Gebrek aan regulering & $-0,153$ & 0,626 & 0,324 & 0,173 & $-0,021$ & $-0,093$ & 1,000 & $-0,009$ & 0,079 \\
\hline 8. Eksterne regulering & 0,480 & 0,309 & 0,047 & 0,406 & 0,462 & 0,263 & $-0,009$ & 1,000 & 0,309 \\
\hline 9. Persoonlike motivering vir studie & 0,406 & 0,185 & 0,140 & 0,368 & 0,420 & 0,270 & 0,079 & 0,309 & 1,000 \\
\hline
\end{tabular}

** Korrelasie is beduidend op die 0,01 vlak van beduidendheid (tweekantig)

* Korrelasie is beduidend op die 0,05 vlak van beduidendheid (tweekantig) 
Uit ' $n$ inspeksie van Tabel 5 blyk dit dat slegs twee van die eigenwaardes groter is as een, gevolglik is twee faktore onttrek (Kaiser, 1961).

Die verkreë faktormatriks is na eenvoudige struktuur geroteer met behulp van die Direct Oblimin-prosedure en verskyn in Tabel 6 .

\section{TABel 6}

GEROTEERDE FAKTORMATRIKS (DIRECT OBLIMIN)

\begin{tabular}{|c|c|c|c|c|c|}
\hline Skale & Skale & K & $\begin{array}{c}\text { Diepte- } \\
\text { benadering } \\
\text { Faktor I }\end{array}$ & $\begin{array}{c}\text { Oppervlak- } \\
\text { benadering } \\
\text { Faktor II }\end{array}$ & $\mathbf{h}_{\mathrm{j}}^{2}$ \\
\hline $\begin{array}{l}\text { 1. Motivering vir } \\
\text { studie (intrinsiek/ } \\
\text { ekstrinsiek) }\end{array}$ & $\begin{array}{l}7,15,18,20,22 \\
24,29,30,39,47 \\
48,59,64\end{array}$ & 13 & 0,779 & $-0,182$ & 0,603 \\
\hline $\begin{array}{l}\text { 2. Reproduserende } \\
\text { oriëntasie }\end{array}$ & $\begin{array}{l}3,8,9,12,13,16 \\
19,26,27,33,35 \\
36,40,41,45,49 \\
51,52,53,55,56 \\
57,60,61,62\end{array}$ & 25 & 0,132 & 0,925 & 0,904 \\
\hline 3. Betekenisoriëntasie & $\begin{array}{l}2,6,10,14,17,21 \\
28,31,34,38,44 \\
46,54\end{array}$ & 13 & 0,064 & 0,404 & 0,174 \\
\hline $\begin{array}{l}\text { 4. Akkumulerings- } \\
\text { begrip van leer }\end{array}$ & $\begin{array}{l}1,2,4,5,6,7,9 \\
10,14,15,16,17 \\
19,20,21,22,24, \\
25,26,27,29,30 \\
31,32,34,35,36, \\
37,39,40,41,42, \\
43,44,45,46,47 \\
50\end{array}$ & 38 & 0,619 & 0,297 & 0,519 \\
\hline $\begin{array}{l}\text { 5. Transformasionele } \\
\text { begrip van leer }\end{array}$ & $\begin{array}{l}3,8,11,12,13,18 \\
23,28,33,38,48 \\
49\end{array}$ & 12 & 0,762 & 0,098 & 0,609 \\
\hline 6. Selfregulering & $\begin{array}{l}7,10,11,13,15 \\
17,21,22,23,25 \\
26,27\end{array}$ & 12 & 0,479 & $-0,191$ & 0,242 \\
\hline $\begin{array}{l}\text { 7. Gebrek aan } \\
\text { regulering }\end{array}$ & $\begin{array}{l}3,4,6,9,12,18 \\
20,32,35,39,48 \\
49,52\end{array}$ & 13 & $-0,141$ & 0,704 & 0,490 \\
\hline $\begin{array}{l}\text { 8. Eksterne } \\
\text { regulering }\end{array}$ & $\begin{array}{l}1,2,5,8,14,16 \\
19,24,28,29,47 \\
53\end{array}$ & 12 & 0,598 & 0,088 & 0,379 \\
\hline $\begin{array}{l}\text { 9. Persoonlike } \\
\text { motivering vir } \\
\text { studie }\end{array}$ & $\begin{array}{l}30,31,33,34,36 \\
37,38,40,41,42, \\
43,44,45,46,50 \\
51\end{array}$ & 16 & 0,525 & 0,090 & 0,297 \\
\hline
\end{tabular}

INTERKORRELASIES VAN FAKTORE

\begin{tabular}{ccc}
\hline Faktor & I & II \\
\hline I & 1,000 & 0,130 \\
II & 0,130 & 1,000 \\
\hline
\end{tabular}

Volgens Tabel 6 is albei die faktore redelik goed bepaal:

Faktor I het hoë ladings op die volgende veranderlikes:

Faktor I

1. Motivering vir Studie $\quad 0,779$

2. Transformasionele begrip van leer $\quad 0,762$

3. Akkumuleringsbegrip van leer $\quad 0,619$

4. Eksterne regulering $\quad 0,598$

5. Persoonlike motivering vir studie $\quad 0,525$

6. Selfregulering 0,479

Aan die hand van die hoë ladings op hierdie faktor kan dit geïdentifiseer word as ' $\mathrm{n}$ dieptebenadering tot leer.

Faktor II het hoë ladings op die volgende veranderlikes:

Faktor II

1. Reproduserende oriëntasie
2. Gebrek aan regulering $\quad 0,704$

3. Betekenisoriëntasie 0,404

Aan die hand van die hoë ladings op hierdie faktor kan dit geïdentifiseer word as ' $\mathrm{n}$ oppervlakbenadering tot leer. Die twee faktore korreleer 0,130 met mekaar en is dus grootliks onafhanklik van mekaar.

\section{BESPREKING}

Uit Tabel 6 blyk dit dat 'n "dieptebenadering tot leer" (Faktor I), vanuit ' $\mathrm{n}$ afstandsonderrig (TV-leer) -paradigma, geassosieer kan word met "motivering vir leer" (intrinsiek, ekstrinsiek en persoonlik), "transformasionele" en "akkumuleringsbegrip" en "self-" en "eksterne regulering". Die "oppervlak-benadering tot leer" (Faktor II) word geassosieer met " $\mathrm{n}$ "reproduserende oriëntasie", "gebrek aan regulering" en in "n mindere mate met "betekenisoriëntasie". Elkeen van die "benaderings tot leer" moet opnuut binne " $n$ nuwe leerkonteks geïnterpreteer word, alhoewel daar tog ' $\mathrm{n}$ mate van konstante individuele verskille teenwoordig is (Entwistle, 1987).

Uit ' $\mathrm{p}$ verdere beskouing van Tabel 6 blyk dit dat die konsepte "diepte-" en "oppervlakbenadering tot leer" (TV-leerkonteks) op sekere eienskappe dui. Die eienskappe strook in sekere opsigte met die definisie en interpretasie van ander skrywers, dog dit verskil ook. Die ooreenkomste behels die volgende: Die "oppervlakbenadering tot leer" word deur die onderhawige studie beskryf as die opneem van 'n "reproduserende oriëntasie" en " $n$ "gebrek aan regulering" wat met die bevindinge van Vermunt (1992) strook. By die beskrywing van die "dieptebenadering tot leer" is daar enersyds bepaalde skale wat tradisioneel met " $n$ "dieptebenadering tot leer" geassosieer word. Die ooreenkomste blyk uit die insluiting van die persoonlike motivering vir studie, transformasionele begrip tot leer en selfregulering van studie. Die beskrywing van die dieptebenadering tot leer sluit andersins skale in wat nie tradisioneel met die dieptebenadering tot leer verband hou nie. Verskille kom voor ten opsigte van die insluiting van die "niepersoonlike motivering", "akkumuleringsbegrip" en "eksterne regulering" van studie. Ofskoon laasgenoemde faktore nie strook met die tradisionele definisie van Entwistle en Tait (1990); Lotriet (1990); en Ramsden (1985) van 'n "dieptebenadering tot leer" nie, postuleer Vermunt (1992) dat studente in 'n afstandsonderrigkonteks wel sukses met "eksterne regulering" tot studie kan behaal. Die insluiting van die nie-tradisionele dieptebenaderingseienskappe in die definisie van die dieptebenadering, in teenstelling wat in die onderhawige studie gepostuleer is (kyk postulaat 1 en 2), blyk dus in die afstandsonderrigkonteks sinvol te wees.

Pintrich (1995) postuleer dat selfregulering ' $\mathrm{n}$ belangrike determinant van sukses vir studente op die kampus is. Hieruit blyk dit dat die definisie van faktore wat verband hou met studiesukses, unieke betekenis in bepaalde leerkontekste aanneem. Die rede hiervoor is dat studente se benaderings tot leer minder konteksgebonde is (Hattingh, 1988), gevolglik hou die "dieptebenadering tot leer" binne die afstands-onderrigkonteks (TV-leer) verband met "intrinsieke", "ekstrinsieke" en "persoonlike motivering vir studies". Die "dieptebenadering tot leer" hou ook verband met "transformasionele" en "akkumuleringsbegrip" asook met "self-" en "eksterne regulering van studies" (kyk Tabel 6). Die "oppervlakbenadering" hou verband met "betekenisoriëntasie" $(0,404)$, "reproduserende oriëntasie" $(0,925)$ en "gebrek aan regulering" $(0,704)$.

Vanuit die onderhawige studie se bevindinge kan ook afgelei word dat die "oppervlakbenadering tot leer" nie verband hou met "motivering vir studie" (intrinsiek, ekstrinsiek en persoonlik) nie. Die "oppervlakbenadering" hou ook nie verband met "begrip van leer" (transformasioneel en akkumuleringsbegrip) en "self-" en "eksterne reguleringstrategieë" nie. 
Pintrich en De Groot (1990) wys op die verband tussen die student se "motivering vir studie" en "selfregulering". Hulle bevindinge word deur die onderhawige studie bevestig (kyk Tabel 6). Daar bestaan ' $n$ betekenisvolle verband tussen "intrinsieke motivering" en die "dieptebenadering tot leer", en "ekstrinsieke motivering" en die "oppervlakbenadering tot leer" (Hattingh, 1988). Daar kan dus afgelei word dat 'n student se "benadering tot leer" deur sy "motivering vir studie" beïnvloed word. Hierdie afleiding word deur die onderhawige studie bevestig, maar slegs ten opsigte van die beskrywing van die "dieptebenadering tot leer" en nie die "oppervlakbenadering tot leer" nie. Gesien in die lig dat verskillende opvattinge oor leer verskillende benaderings tot leer verteenwoordig, word Hattingh (1988) se vermoede dat daar ' $n$ verband bestaan tussen die student se "begrip van leer" en sy "benadering tot leer", deur die onderhawige studie bevestig (kyk Tabel 4).

Uit die voorafgaande kan dus gepostuleer word dat die "dieptebenadering tot leer", wat normaalweg met sukses in hoër onderwys geassosieer word, anders in die afstandsonderrigkonteks (TV-leer) gedefinieer moet word. Die "dieptebenadering tot leer" word in die betrokke konteks nie net beïnvloed deur ' $\mathrm{n}$ student se begrip van leer, werkslading, selfvertroue, fokus op detail en die tydsfaktor nie (Marton \& Saljo, 1976), maar ook deur ander faktore. In dié spesifieke leerkonteks word "self-en eksterne regulering", "transformasionele-en akkumuleringsbegrip" en "intrinsieke, ekstrinsieke en persoonlike motivering vir studie" onder dieselfde konstruk ("dieptebenadering tot leer") ingesluit. Hierdie bevindinge bevestig die behoefte aan ' $n$ wegbreek van die tradisionele definisie van faktore wat met studiesukses in die hoër onderwys verband hou. Dit impliseer dat daar voorsiening gemaak moet word vir 'n wyer verskeidenheid van strategieë wat leerders in bepaalde leerkontekste kan opneem. Dit wys op die behoefte aan erkenning van die uniekheid van leerders en die uitbou van navorsers se soeke na betekenis in bepaalde leerkontekste.

Binne die televisieleerkonteks is dit belangrik dat leerders toegelaat sal word om ' $\mathrm{n}$ verskeidenheid van leerbenaderings in die leerproses te benut. Dit sal leerders in staat stel om breër konseptuele en perseptuele beskouinge, byvoorbeeld taak-en evalueringsvereistes, te ontwikkel en die geskikste leerbenadering in die leerproses te benut. Die uniekheid van die televisieleerkonteks asook die eiesoortige eise wat aan dié konteks gestel word, word deur die onderhawige studie bevestig.

Voorts is terminologiese verwarring en omslagtige benutting van terminologie deur dié studie uitgeskakel. In hierdie studie is die grondslag gelê vir die daarstelling van betroubare en geldige skale wat in die televisieleerkonteks benut kan word, wat die dinamika van die sistemiese komponente in die unieke konteks reflekteer. Hierdeur kan leerders en leerbegeleiers groter insig verkry in die strukturering en aanbieding van die leerinhoud sowel as die skep van 'n gunstige leeromgewing.

\section{VERWYSINGS}

Akande, A. (1998). Towards the multicultural validation of a Western model of students' approaches to learning. Education, 119(1), 37-47.

Biggs, J.B. (1985). The role of meta-learning in study processes. British Journal of Education Psychology, 55(3), 185-212.

Biggs, J.B. (1989). Approaches to the enhancement of tertiary teaching. Higher Education Research and Development, 8(1), 7-25.

Biggs, J.B. (1993). From theory to practice: A cognitive systems approach. Higher Education Research and Development, 12(1), 73-83.

Biggs, J.B. (1995). Learning in the classroom. In J. Biggs \& D. Watkins (eds.), Classroom learning: Educational Psychology for the Asian teacher (pp. 147-166). Singapore: Prentice-Hall.

Brinkerhoff, R.O. (1987). Achieving results from training: How to evaluate human resource development to strengthen programs and increase impact. San Francisco, C.A.: Jossey-Bass.

Broad, M.L. \& Newstrom, J.W. (1992). Transfer of training: Actionpacked strategies to ensure high payoff from training investments. Reading, MA: Addison- Wesley.

Burke, L.A. (1997). Improving positive transfer: A test of relapse prevention training on transfer outcomes. Human Resource Development Quarterly, 8(2), 115-127.

Dickinson, D. (1999). Positive trends in learning: Meeting the needs of a rapidly changing world. [Online]. <http://www.newhrozons.org.>[1999, April 10].

Durr, R., Guglielmino, M. \& Guglielmino, P.J. (1996). Selfdirected learning readiness and occupational categories. Human Resource Development Quarterly, 7(4), 349-358.

Entwistle, N. (1987). Motivation to learn: Conceptualisations and practicalities. British Journal of Education Studies, 35(2), $129-148$.

Entwistle, N. \& Tait, H. (1990). Approaches to learning, evaluations of teaching, and preferences for contrasting academic environments. Higher Education, 19(2), 169-194.

Entwistle, N. (1992). Student learning and study strategies. In The Encyclopedia of Higher Education (pp. 1730-1749). Oxford: Pergamon.

Entwistle, N. \& Ramsden, P. (1983). Understanding student learning. London: Nicholas Publishing Company.

Ford, J.K. \& Noe, R.A. (1987). Self-Assessed training needs: The effects of attitudes toward training, managerial level and function. Personnel Psychology, 40(1), 39-53.

Ford, J.K. \& Weissbein, D.A. (1997). Transfer of training: An updated review and analysis. Performance Improvement Quarterly, 10(2), 22-41.

Gallagher, J.J. (1994). Teaching and learning: New models. Annual Review of Psychology, 45, 171-195.

Greyling, E.S.G. (1993). Kriteria vir afstandsonderwysprogramme aan residensiële Suid-Afrikaanse Universiteite. Ongepubliseerde doktorale proefskrif, Randse Afrikaanse Universiteit, Johannesburg.

Hackman, M.Z. \& Walker, K.B. (1990). Instructional communication in the televised classroom: The effects of system design and teacher immediacy on student learning and satisfaction. Communication Education, 39(3), 196-206.

Hattingh, D.L. (1988). 'n Empiriese ondersoek oor hoe studente leer. Pretoria: RGN.

Holton, E.F. (1996). The flawed four-level model. Human Resource Development Quarterly, 7(1), 5-19.

Howard, S.W. \& Ault, M.M. (1992). Distance education: Promises and cautions for special education. Teacher Education and Special Education, 15(4), 275-283.

Kaiser, H.F. (1961). A note on Guttman's lower bound for the number of common factors. British Journal of Statistical Psychology, 14(1), 1.

Knowles, M.S. (1984). Andragogy in action: applying modern principles of adult learning. San Francisco, C.A.: Jossey-Bass.

Knowles, M.S. (1989). The making of an adult educator. San Francisco, C.A.: Jossey-Bass.

Knowles, M.S., Holton, E.F. \& Swanson,R.A. (1998). The adult learner: The definite classic in adult education and human resource development. Houston: Gulf Publishing Company.

Lotriet, A. (1990). Onderrigstrategiëe vir die ontwikkeling van betekenisvolle leer by eerstejaaropvoedkundestudente aan die Universiteit van Vista. Ongepubliseerde doktorale proefskrif, Randse Afrikaanse Universiteit, Johannesburg.

Marshall, D. \& Summers, M. (1999). Students' conceptions of learning in an engineering context. Higher Education, 38(3), 291-310.

Mathieu, J.E., Tannenbaum, S.I. \& Sallas, E. (1992). Influences of individual and situational characteristics on measures of training effectiveness. Academy of Management Journal, 35, 828-847.

Marton, F. \& Saljo, R. (1976). On qualitative differences in learning outcome as a function of the learners conception of the task. British Journal of Educational Psychology, 46(2), 115-127. 
Marton, F. \& Saljo, R. (1984). Approaches to learning. In F. Marton., D. Hounsell, \& N.J. Entwistle (Eds.), The experience of learning (pp. 36-55). Edinburgh: Scottish Academic Press.

Meyer, J.H.F \& Boulton-Lewis, G.M. (1999). On the operationalisation of conceptions of learning in higher education and their association with students' knowledge and experiences of their learning. Higher Education Research and Development, 18(3), 289-302.

Mji, A. (1998). Conceptions of learning: Views of undergraduate mathematics students. Psychological Reports, 83(3), 982-982.

Mji, A. \& Glencross, M.J. (1999). An examination of first-year university students' attitudes toward approaches to learning. Psychological Reports, 85(3), 809-816.

Morgan, A. (1993). Improving your students' learning. Reflections on the experience of study. London: Kogan Page.

Noe, R.A. (1986). Trainees' attributes and attitudes: Neglected influences on training effectiveness. Academy of Management Review, 11, 736-749.

Parsons, P.G. (1992). An investigation into the association between qualitatively different perceptions of learning context and students' approaches to studying. Unpublished doctoral thesis, University of Cape Town, Cape Town.

Phipps, R. \& Merisotis, J. (1999). What's the difference?: A review of contemporary research on the effectiveness of distance learning in higher education. [Online]. The Institute for Higher Education Policy. <(difference.pdf from)www. ihep. comm> [1999, April. 8].

Pintrich, P.R. \& De Groot, E. (1990). Motivational and selfregulated components of classroom academic performance. Journal of Educational Psychology, 82, 33-40.

Pintrich, P.R. (1995). Understanding self-regulated learning. New directions for teaching and learning. San Francisco: Jossey-Bass.

Ramsden, P. \& Entwistle N.J. (1981). Effects of academic departments on students' approaches to studying. British Journal of Educational Psychology, 51(3), 368-383.

Ramsden, P. (1983). The Lancaster Approach to Studying and Course Perception Questionnaire. Lecturer's Handbook. Oxford: Oxford Poly Technic.

Ramsden, P. (1985). Student learning research: Retrospect and prospect. Higher Education Research and Development, 4(1), 51-69.

Richardson, J.T.E. \& Morgan, A. (1999). Approaches to studying in distance education. Higher Education, 37(1), 23-56.

Rossouw, P. \& Parsons, P.G. (1994). An exploration of the association between students' approaches to learning and their perceived locus of control. Paper presented at the Second Improving Student Learning Symposium, United Kingdom.
Saljo, R. (1982). Learning and understanding: A study of differences in constructing meaning from a text. Gottenburg: Acta Universitatis Gothoburgensis.

Schmeck, R.R. (ed.) (1988). Learning strategies and learning styles. New York: Plenum Press.

Schunk, D.H. (1986). Verbalization and children's self-regulated learning. Contemporary Educational Psychology, 11, 347-369.

Slabbert, J.A. \& De Villiers, A.S. (1998). The South African organizational environment. Johannesburg: La Digma.

Tannenbaum, S.I., Mathieu, J.E., Sallas, E. \& Cannon-Bowers, J. A. (1991). Meeting trainees' expectations: The influence of training fulfillment on the development of commitment, self-efficacy and motivation. Journal of Applied Psychology, 76(6), 759-769.

Tannenbaum, S.I. \& Yukl, G. (1992). Training and development in work organizations. Annual Review of Psychology, 43, 399441.

Tziner, A. \& Falbe, C.M. (1993). Training related variables, gender and training outcomes: A field investigation. International Journal of Psychology, 28(2), 203-221.

Van Dyk, P.S., Nel, P.S., Loedolff, P. \& Haasbroek, G.D. (1997). Training management: A multidisciplinary approach to human resources development in Southern Africa. Johannesburg: International Thomson.

Van Wyk, G.J. (1990). Die leerstrategiee van eerste-aarstudente aan die $R A U$. Ongepubliseerde Magisterverhandeling, Randse Afrikaanse Universiteit, Johannesburg.

Van Zyl, K. (1991). Leergereedheid by volwassenes in die werksituasie. Ongepubliseerde Magisterverhandeling, Randse Afrikaanse Universiteit, Johannesburg.

Vermunt, Jan D.H.M. (1992). Leerstijlen en sturen van leerprocessen in het hoger onderwijs. Naar procesgerichte instruktie in zelfstandige denken. (Leerstyle en die regulering van die leerproses in die hoër onderwys. Prosesgerigte onderwys in selfstandige denke). Alblasserdam: Offsetdrukkerij Kansters B.V.

Vermunt, Jan D.H.M. (1994). Inventory of Learning Styles in Higher Education. ICLON-Graduate School of Education, Leiden University, The Netherlands.

Warr, P. \& Bunce, D. (1995). Trainee characteristics and the ontcomes of open learning. Personnel Psychology, 48(2), 347-375.

Wexley, K.N. \& Latham, F.P. (1981). Developing and training human resources in organisations. Glenview: Scott, Foresman.

Wlodkowski, R.J. (1985). Enhancing adult motivation to learn. San Francisco, C.A.: Jossey-Bass.

Zhang, L. (2000). University students' learning approaches in three cultures. Journal of Psychology Interdisciplinary \& Applied, 134(1), 37-56. 